\title{
EXPLORING THE IMPACT OF EMPATHY, COMPASSION, AND MACHIAVELLIANISM ON CONSUMER ETHICS IN AN EMERGING MARKET
}

\begin{abstract}
The purpose of this study is to explore the impact of positive personality traits (i.e., empathy and compassion) and negative personality traits (i.e., Machiavellianism) on consumer ethics in Indonesia. This is one of the first studies to explore this topic in relation to Indonesia, which is the fourth most populous country in the world. Based on a convenience sample of 540 respondents, the results showed that cognitive empathy and compassion negatively impacted consumers' perception toward various unethical behaviors, while desire for control and distrust of others positively influenced such behaviors. Based on earlier studies showing that the younger generation has less empathy than previous generations, the findings of the present study have important implications for creating a more empathetic and compassionate society.
\end{abstract}

Keywords consumer ethics, empathy, compassion, Machiavellianism, Indonesia 


\section{Introduction}

Recently, there has been increased attention focused on understanding the impact of positive and negative personality traits among younger generations (Batson et al., 2002; Dovidio \& Penner, 2001). For example, one study reported that college students today show $40 \%$ less empathy than students in the 1980s and 1990s (Anderson \& Konrath, 2011). Another study found that affluent individuals are less likely to report feeling empathy and compassion toward others on a regular basis (Piff et al., 2012). Other studies have shown that those who act in an antisocial manner have less empathy and compassion than those who are not socially offensive (Burke 2001; Bush et al., 2000; Jolliffe \& Farrington, 2004; Marcus \& Gray, 1998). The acquisition of empathy and compassion and the exclusion of Machiavellianism are considered to be essential factors for adequate moral development (Enderle et al. 2012; Jollifee \& Farrington, 2006).

Previous studies have found empirical evidence for a positive correlation between empathy and compassion and various pro-social behaviors (Batson et al., 1987; Jollifee \& Farrington, 2006). Pro-social behavior can be defined as behavior that is intended to help other people, usually based on concern for the feelings and welfare of others and often without involving any monetary gain (George \& Bettenhausen, 1990). Other studies have investigated the impact of empathy (Eisenberg et al., 1985; Toi \& Batson, 1982), compassion (Sprecher \& Fehr, 2005), and Machiavellianism (Hawley, 2003) on pro-social behaviors. Despite the relationship between these personality traits and pro-social behavior, the impact of personality traits on consumer ethical behaviors is distinct from the effects on pro-social behaviour (Vitell, 2003). However, few studies have focused on the relationship between personality traits and consumer ethical behaviors. Accordingly, the purpose of this study is to explore the impact of positive personality traits (i.e., empathy and compassion) and negative personality traits (i.e., Machiavellianism) on consumer ethics in Indonesia. This is one of the 
first studies to explore this issue in Indonesia, which is the fourth most populous country in the world.

\section{Literature Review and Hypothesis Development}

To acquire further insights into the impact of empathy, compassion and Machiavellianism on consumer ethics, the literature review section offers definitions and previous research findings on these issues. This section will begin by outlining the extant literature on consumer ethics, as the dependent variables followed by empathy, compassion and Machiavellianism as independent variables.

\section{Consumer Ethics}

Ethical issues have received considerable attention from researchers over the last few decades (Al-Khatib et al., 1997; Vitell, 2003). Muncy and Vitell (1992) defined consumer ethics as "the moral principles and standards that guide behavior of individuals or groups as they obtain, use and dispose of goods and services" (p. 298) and designed the most widely used construct for consumer ethics, the consumer ethics scale (CES). The scale examines consumer perception toward various consumers' situations having potentially ethical implications (Muncy and Vitell, 1992; Rawwas, 1996) and has four dimensions: (a) actively benefiting from illegal activities (ACTIVE), which deals with illegal actions initiated by consumers; (b) passively benefiting at the expense of others (PASSIVE), where the consumer benefits from the seller's mistake; (c) benefiting from questionable, but legal, behavior (QUEST), where the consumer initiates activities that are unlikely to be perceived as illegal; and (d) no harm/no foul activities (NO HARM), where the consumer perceives little or no harm to others. Most consumers report that it is more ethical to benefit from a PASSIVE activity than from an ACTIVE activity. In addition, consumers report that benefiting from a 
PASSIVE activity is more unethical than benefiting from QUEST activities and that NO HARM activities are generally acceptable and more ethical than the other three activities (Vitell \& Paolillo, 2003).

Recently, Vitell and Muncy (2005) updated the scale by adding three new dimensions: (a) downloading or buying counterfeit goods (DOWNLOAD), where it measures consumers' perception toward buying non-genuine or pirated products; (b) recycling and environmental awareness (RECYCLE), where it measures consumers' perception toward involvement in pro-environment activities; and (c) doing the right thing (DOING GOOD), where it measures consumers' perception toward showing kindness and honesty toward others. The first of these, DOWNLOAD, and the previous four categories described above (ACTIVE, PASSIVE, QUEST, and NO HARM) are measuring the level of agreement toward situations having potentially negative implications while the last two categories (RECYCLE and DOING GOOD) are measuring the level of agreement toward situations having potentially positively implications. The present study employed the updated CES containing all seven dimensions of consumers' perception of consumer situations having potentially ethical implications.

Despite suggestions from marketing ethics theory that ethical decision making varies based on the personal characteristics of the decision maker (Ferrel \& Gresham, 1985; Hunt \& Vitel, 1986, 1992), only a few studies have investigated the impact of personality traits on consumer ethics. For example, Rallapalli et al. (1994) found that individuals with high needs for autonomy, innovation, aggression, and risk taking were more likely to have fewer ethical beliefs. In addition, most of these studies were conducted mainly in developed countries, such as the United States (Muncy \& Eastman, 1998; Muncy \& Vitell, 1992; Rallapalli et al., 1994; Rawwas \& Singhapakdi, 1998; Strutton et al., 1994; Vitell et al., 2001; Vitell \& Muncy, 1992), Australia (Rawwas et al., 1996), Northern Ireland (Rawwas et al., 1998), and 
Belgium (Van Kenhove et al., 2001). Thus, there is a need to further investigate the relationship between personality traits and consumer ethical beliefs across different cultures (Al-Khatib et al., 1997; Rallapali et al., 1994).

\section{Empathy}

Empathy can be considered as the propensity to indirectly experience the emotional states of others or an emotional response that is focused more on others than on self (Davis, 1994). To empathize means to feel the emotions of others, or at least similar emotions (Eisenber \& Miller, 1987); the emotional response can be either identical or congruent with what others are experiencing (Albiero et al., 2009; Eisenberg et al., 1994). Studies have found correlations between empathy and various pro-social behaviors, such as volunteering time to help others (Barnet et al., 1983; Barnett \& Thompson, 1985; Earle et al., 1982; Fultz et al., 1986) or donating money to others in need (Batson et al., 1979; Brehm et al., 1984; Coke, 1980; Eisenberg, 1983). In addition, lack of empathy is correlated with psychopathy or behavioral traits linked to criminal behavior (Harpur et al., 1988). Finally, empathy is positively correlated with social intelligence and may reduce all forms of aggression among youth (Albiero et al., 2009; Bandura, 1999; Jollifee \& Farrington, 2004; Miller \& Eisenberg, 1988).

An individual's ability to understand the emotional states of others can be categorized as: (1) affective or emotional empathy, which is the ability to experience the emotions of another, and (2) cognitive empathy, which is the ability to comprehend the emotions of another (Eisenberg \& Miller, 1987; Jolliffe \& Farington, 2005; Underwood \& More, 1982). Lack of empathy may be associated with antisocial behavior and aggressiveness. An individual who is able to comprehend the emotional consequences of their behavior toward others may be less inclined to act in an antisocial manner in the future (Fesbach, 1975; 
Jolliffe \& Farrington, 2006). In addition, an individual who is able to empathize will act more ethically than an individual who is lacking in empathy. Accordingly, the following hypotheses are proposed:

H1: Affective empathy is a negative determinant of consumer ethical beliefs regarding ACTIVE behavior $\left(\mathrm{H}_{1 \mathrm{~A}}\right)$, PASSIVE behavior $\left(\mathrm{H}_{1 \mathrm{~B}}\right)$, QUEST behavior $\left(\mathrm{H}_{1 \mathrm{C}}\right)$, NO HARM behavior $\left(\mathrm{H}_{1 \mathrm{D}}\right)$, and DOWNLOAD behavior $\left(\mathrm{H}_{1 \mathrm{E}}\right)$ and a positive determinant of RECYCLE behavior $\left(\mathrm{H}_{1 \mathrm{~F}}\right)$ and DOING GOOD behavior $\left(\mathrm{H}_{1 \mathrm{G}}\right)$.

H2: Cognitive empathy is a negative determinant of consumer ethical beliefs regarding ACTIVE behavior $\left(\mathrm{H}_{2 \mathrm{~A}}\right)$, PASSIVE behavior $\left(\mathrm{H}_{2 \mathrm{~B}}\right)$, QUEST behavior $\left(\mathrm{H}_{2} \mathrm{C}\right)$, NO HARM behavior $\left(\mathrm{H}_{2 \mathrm{D}}\right)$, and DOWNLOAD behavior $\left(\mathrm{H}_{2 \mathrm{E}}\right)$ and a positive determinant of RECYCLE behavior $\left(\mathrm{H}_{2 \mathrm{~F}}\right)$ and DOING GOOD behavior $\left(\mathrm{H}_{2 \mathrm{G}}\right)$.

\section{Compassion}

Compassion is a positive personality trait that can be defined as an "attitude toward other(s), either close others or strangers of all humanity; containing feelings, cognitions, and behaviors that are focused on caring, concern, tenderness, and an orientation toward supporting, helping, and understanding the others" (Sprecher \& Fehr, 2005, p. 630) or "being moved by another's suffering and wanting to help" (Lazarus, 1991, p. 289). The difference between compassion and empathy is that compassion is an other-directed emotion that often excludes attempts to understand the intensity of another person's pain or problem. In contrast, empathy is focused on sharing the emotional state of others and understanding their pain or problem (Lazarus, 1991; Specher \& Fehr, 2005). Studies have reported a correlation between compassion and increased pro-social behaviors (Dovido \& Penner, 2001; Leiberg et al., 2011; Specher \& Fehr, 2005). Developing compassion among individuals brings positive benefits (Hwang et al., 2008). Peterson and Seligman (2004) suggested that compassion is associated with a sense of vocation in helping a person to make a positive contribution to the world. An individual with a compassionate personality will avoid unethical behaviors because that person will understand the unintended consequences of unethical behaviors toward others. Accordingly, the following hypothesis is proposed: 
H3: Compassion is a negative determinant of consumer ethical beliefs regarding ACTIVE behavior $\left(\mathrm{H}_{3 \mathrm{~A}}\right)$, PASSIVE behavior $\left(\mathrm{H}_{3 \mathrm{~B}}\right)$, QUEST behavior $\left(\mathrm{H}_{3 \mathrm{C}}\right)$, NO HARM behavior $\left(\mathrm{H}_{3 \mathrm{D}}\right)$, and DOWNLOAD behavior $\left(\mathrm{H}_{3 \mathrm{E}}\right)$ and a positive determinant of RECYCLE behavior $\left(\mathrm{H}_{3 \mathrm{~F}}\right)$ and DOING GOOD behavior $\left(\mathrm{H}_{3 \mathrm{G}}\right)$.

\section{Machiavellianism}

Machiavellianism as a personality construct has its roots in the negative aspects of management and leadership (Christie \& Geis, 1970; Griffin \& O’Leary-Kelly, 2004). Machiavellianism can be defined as "a process by which the manipulator gets more of some kind of reward than he would have gotten without manipulating, and someone else gets less, at least within the immediate context" (Christie \& Geis, 1970, p. 107). Dahling et al. (2009) argued that Machiavellianism is a complex set of characteristics that may include several dimensions, such as desire to control and distrust of others. The author defined the desire to control as "a need to exercise dominance over interpersonal situations to minimize the extent to which others have power" and distrust of others as "a cynical look on the motivations and intentions of others with a concern for the negative implications that those intentions have for the self" (Dahling et al., 2009, p. 228).

Various studies have investigated the impact of Machiavellianism on consumer ethics and have shown that people with a high degree of Machiavellian personality traits believe that unethical consumer practices are more acceptable, while people with a low degree of Machiavellian personality traits perceive these practices to be less acceptable (Al-Khatib et al., 1997; Erffmeyer et al., 1999; Rawwas, 1996; Vitell et al., 1991). Other studies have found a positive correlation between Machiavellianism and pro-social behavior. Individuals with a high degree of Machiavellian personality traits are less likely to engage in helping behaviors than individuals with a low degree of Machiavellian personality traits (Wolfson, 1981). Machiavellian personalities possess a "cool detachment" that makes them less emotionally engaged with others or less concerned with saving face in a potentially 
embarrassing situation that arises as a consequence of their actions (Christie \& Geis, 1970;

Vitell et al., 1991). Therefore, the following hypotheses are proposed:

H4: Desire to control is a positive determinant of consumer ethical beliefs regarding ACTIVE behavior $\left(\mathrm{H}_{4 \mathrm{~A}}\right)$, PASSIVE behavior $\left(\mathrm{H}_{4 \mathrm{~B}}\right)$, QUEST behavior $\left(\mathrm{H}_{4 \mathrm{C}}\right), \mathrm{NO}$ HARM behavior $\left(\mathrm{H}_{4 \mathrm{D}}\right)$, and DOWNLOAD behavior $\left(\mathrm{H}_{4 \mathrm{E}}\right)$ and a positive determinant of RECYCLE behavior $\left(\mathrm{H}_{4 \mathrm{~F}}\right)$ and DOING GOOD behavior $\left(\mathrm{H}_{4 \mathrm{G}}\right)$.

H5: Distrust of others is a positive determinant of consumer ethical beliefs regarding ACTIVE behavior $\left(\mathrm{H}_{5 \mathrm{~A}}\right)$, PASSIVE behavior $\left(\mathrm{H}_{5 \mathrm{~B}}\right)$, QUEST behavior $\left(\mathrm{H}_{5 \mathrm{C}}\right)$, NO HARM behavior $\left(\mathrm{H}_{5 \mathrm{D}}\right)$, and DOWNLOAD behavior $\left(\mathrm{H}_{5 \mathrm{E}}\right)$ and a positive determinant of RECYCLE behavior $\left(\mathrm{H}_{5 \mathrm{~F}}\right)$ and DOING GOOD behavior $\left(\mathrm{H}_{5 \mathrm{G}}\right)$.

\section{Methodology}

Sample

Data were obtained from a convenience sample of undergraduate students at a large private university in Indonesia. Indonesia is the fourth most populous nation in the world (approximately 240 million people) and is the largest country in Southeast Asia (Population Reference Bureau, 2011). With the exception of China, the Indonesian economy is growing faster than any other major emerging market economy, with 6.5\% growth in 2011 (CIA World Factbook, 2013). The Gross Domestic Product (GDP) per capita was estimated at $\$ 5,000$ in 2012 , with an unemployment rate of $6.1 \%$. In addition, $11.7 \%$ of the population lived below the poverty line in 2012 (CIA World Factbook, 2013). Indonesia scored only 32 on the latest corruption perception index compared to US (73) and New Zealand (91) (Transparency International, 2013).

The researchers hand-delivered approximately 600 questionnaires to students in their classrooms. Participants returned 576 questionnaires, yielding a response rate of 96\%. Incomplete questionnaire were removed resulted in 540 questionnaires, yielding an overall response rate of $90 \%$. A back translation method was used to ensure the reliability of the questionnaires, whereby a professor of linguistics read the translation and discussed any discrepancies with the translator until a consensus was reached. The demographic profile of 
respondents indicated that there were more female than male respondents $(67 \%$ and $33 \%$, respectively), most were single (92\%), 83\% were between the ages of 18 and 20 years, and $14 \%$ were between the ages of 21 and 23 years. Table 1 summarises the demographic profile of respondents.

\section{Insert Table 1 About Here}

\section{Measures and Reliability}

Consumer ethics were measured using the updated CES (Vitell \& Muncy, 2005). The scale consists of 29 items that measure the seven dimensions of consumer behaviour: (1) actively benefiting from illegal activities (ACTIVE; e.g., drinking a can of soda in a store without paying for it), (2) passively benefiting (PASSIVE; e.g., not saying anything when the waitress miscalculates the bill in your favour), (3) questionable, but legal, behavior (QUEST; e.g., stretching the truth on an income tax return), (4) no-harm/no-foul behavior (NO HARM; e.g., burning a copy of a CD instead of buying it), (5) downloading or buying counterfeit goods (DOWNLOAD; e.g., downloading music from the Internet instead of buying it), (6) recycling and environmental awareness (RECYCLE; e.g., recycling materials such as cans, bottles, and newspapers), and (7) doing the right thing (DOING GOOD; e.g., giving a largerthan-expected tip to a waiter). The reliability of the seven dimensions on the CES was as follows: ACTIVE (4 items), $\alpha=0.626$; PASSIVE ( 3 items), $\alpha=0.730$; QUEST ( 5 items), $\alpha=$ 0.745; NO HARM (3 items), $\alpha=0.660$; DOWNLOAD (2 items), $\alpha=0.682$; RECYCLE (3 items), $\alpha=0.549$; and DOING GOOD (2 items), $\alpha=0.500$. Respondents rated each behavior on a 5-point Likert-type scale ranging from $1=$ strongly disagree to $5=$ strongly agree. A high score indicates that consumers consider a particular action as more acceptable or ethical.

Empathy was measured using the basic empathy scale (BES) developed by Jolliffe and Farrington, (2006). The scale is made up of two subscales identifying two different components of empathic responsiveness: affective empathy and cognitive empathy (Albiero 
et al., 2008; Jollife \& Farrington, 2006). Affective empathy was assessed using 11 items that measure emotional congruence with another person's emotions. One example of such an item on the BES is "my friend's emotions don't affect me much 9r)." Cognitive empathy was assessed using 9 items that measure an individual's ability to understand another person's emotions. An example of such an item is "I can often understand how people are feeling even before they tell me." Respondents rated each item on a 5-point Likert-type scale ranging from $1=$ strongly disagree to $5=$ strongly agree. A high score indicates more empathy toward others. The reliability of the two dimensions on the BES was as follows: AFFECTIVE EMPATHY (4 items), $\alpha=0.797$ and COGNITIVE EMPATHY (8 items), $\alpha=$ 0.846 .

Compassion was measured by a briefer version of a compassionate love scale known as the Santa Clara Brief Compassion Scale (SCBCS) and developed by Hwang et al. (2008). The scale consists of 5 items that are ideal for use in educational and religious institutions (Hwang et al., 2008). A sample item is "I tend to feel compassion for people, even though I do not know them." Respondents rated each item on a 5-point Likert-type scale ranging from $1=$ strongly disagree to $5=$ strongly agree. A high score indicates more compassion toward others. The reliability of this single dimension was $\alpha=0.799$ (5 items).

A new Machiavellianism scale developed by Dahling et al. (2008) was used to measure two personality traits: control over others and distrust of others. The reliability of the two dimensions was as follows: DESIRE FOR CONTROL ( 3 items), $\alpha=0.830$ and DISTRUST OF OTHERS (5 items), $\alpha=0.792$.

Table 2 shows the mean value for each scale and the correlation scores between variables. Table 3 summarises all scale items used in this study, including factor loadings and reliability scores. 


\section{Results}

Separate multiple regression analyses were employed to test the relationship between the independent variables (affective empathy, cognitive empathy, compassion, desire for control, and distrust of others) and the dependent variables (the seven dimensions of consumer ethical behavior). Results are shown in Table 4.

\section{Insert Table 4 About Here}

Affective Empathy

Affective empathy had a positive impact on QUEST behavior $(\beta=0.093, \mathrm{p}=0.026)$ and DOWNLOAD behavior $(\beta=0.207 ; \mathrm{p}=0.000)$, which is opposite to that predicted by $\mathrm{H}_{1 \mathrm{C}}$ and $\mathrm{H}_{1 \mathrm{E}}$. Moreover, affective empathy did not significantly explain ACTIVE, PASSIVE, NO HARM, RECYCLING, or DOING GOOD behaviors. Thus, $\mathrm{H}_{1 \mathrm{~A}}, \mathrm{H}_{1 \mathrm{~B}}, \mathrm{H}_{1 \mathrm{C}}, \mathrm{H}_{1 \mathrm{D}}, \mathrm{H}_{1 \mathrm{E}}, \mathrm{H}_{1 \mathrm{~F}}$, and $\mathrm{H}_{1 \mathrm{G}}$ are rejected.

\section{Cognitive Empathy}

Cognitive empathy had a negative impact on ACTIVE $(\beta=-0.098 ; \mathrm{p}=0.042), \operatorname{PASSIVE}(\beta$ $=-0.120 ; \mathrm{p}=0.012)$, and QUEST $(\beta=-0.133 ; \mathrm{p}=0.004)$ behaviors and a positive impact on DOING GOOD behaviors $(\beta=0.114 ; \mathrm{p}=0.020)$. However, cognitive empathy did not significantly affect NO HARM, DOWNLOAD, or RECYCLE behaviors. Thus, $\mathrm{H}_{2 \mathrm{~A}}, \mathrm{H}_{2 \mathrm{~B}}$, $\mathrm{H}_{2 \mathrm{C}}$ and $\mathrm{H}_{2 \mathrm{G}}$ are supported and $\mathrm{H}_{2 \mathrm{D}}, \mathrm{H}_{2 \mathrm{E}}$, and $\mathrm{H}_{2 \mathrm{~F}}$ are rejected.

\section{Compassion}

Compassion had a negative impact on ACTIVE $(\beta=-0.158 ; \mathrm{p}=0.001), \operatorname{PASSIVE}(\beta=-$ 0.168; $\mathrm{p}=0.000)$, and QUEST $(\beta=-0113 ; \mathrm{p}=0.014)$ behaviors and a positive impact on RECYCLE $(\beta=0.153 ; \mathrm{p}=0.002)$ and DOING GOOD $(\beta=0.141 ; \mathrm{p}=0.004)$ behaviors. 
Thus, $\mathrm{H}_{3 \mathrm{~A}}, \mathrm{H}_{3 \mathrm{~B}}, \mathrm{H}_{3 \mathrm{C}}, \mathrm{H}_{3 \mathrm{~F}}$, and $\mathrm{H}_{3 \mathrm{G}}$ are supported. However, compassion did not significantly explain NO HARM and DOWNLOAD behaviors. Thus, $\mathrm{H}_{3 \mathrm{D}}$ and $\mathrm{H}_{3 \mathrm{E}}$ are rejected.

\section{Desire for Control}

Desire for control had a positive impact on ACTIVE $(\beta=0.128 ; \mathrm{p}=0.005)$, PASSIVE $(\beta=$ $0.110 ; \mathrm{p}=0.014)$, QUEST $(\beta=0.158 ; \mathrm{p}=0.000)$, and NO HARM $(\beta=0.174 ; \mathrm{p}=0.000)$ behaviors. Thus, $\mathrm{H}_{4 \mathrm{~A}}, \mathrm{H}_{4 \mathrm{~B}}, \mathrm{H}_{4 \mathrm{C}}$, and $\mathrm{H}_{4 \mathrm{D}}$ are supported. Furthermore, desire for control did not significantly explain DOWNLOAD, RECYCLE, and DOING GOOD behaviors. Thus, $\mathrm{H}_{4 \mathrm{E}}, \mathrm{H}_{4 \mathrm{~F}}$, and $\mathrm{H}_{4 \mathrm{G}}$ are rejected.

\section{Distrust of Others}

Distrust of others had a negative impact on ACTIVE $(\beta=0.143 ; \mathrm{p}=0.005), \operatorname{PASSIVE}(\beta=$ $0.181 ; \mathrm{p}=0.000)$, QUEST $(\beta=0.217 ; \mathrm{p}=0.000)$, NO HARM $(\beta=0.413 ; \mathrm{p}=0.002)$, and DOWNLOAD $(\beta=0.206 ; \mathrm{p}=0.000)$ behaviors. Thus, $\mathrm{H}_{5 \mathrm{~A}}, \mathrm{H}_{5 \mathrm{~B}}, \mathrm{H}_{5 \mathrm{C}}, \mathrm{H}_{5 \mathrm{D}}$, and $\mathrm{H}_{5 \mathrm{E}}$ are supported. However, distrust of others did not significantly explain RECYCLE and DOING GOOD behaviors. Hence, $\mathrm{H}_{5 \mathrm{~F}}$ and $\mathrm{H}_{5 \mathrm{G}}$ are rejected. Table 5 summarizes the hypothesis results.

\section{Insert Table 5 About Here}

\section{Discussion}

Empathy

The results show that cognitive empathy, defined as the ability to understand another person's emotions, had a negative influence on consumers' perception toward most unethical behaviors and a positive influence on consumers' perception toward willingness to engage in DO GOOD behaviors. These findings suggest that consumers with cognitive empathy are less likely to behave unethically and more likely to perform good deeds toward others. 
In contract, affective empathy, defined as emotional congruence with another person's emotions, positively influenced some unethical behaviors (questionable behavior and downloading). These results suggest that consumers with higher affective empathy are more likely to engage in questionable, but legal, behaviors and to engage in the downloading or purchasing of counterfeit goods. Thus, not all empathy can be viewed as a protective factor that decreases the probability that an individual will engage in certain types of unethical behavior. The conclusion from these results is that cognitive empathy is more likely to reduce consumer unethical behaviors than affective empathy.

Jollifee and Farrington (2004) suggested that affective empathy often occurs unconsciously; thus, it is difficult to increase or decrease affective empathy (Staub, 1987). However, cognitive empathy is a skill that people can learn and develop (Block-Lerner, 2007). The present study found that cognitive empathy had a greater effect on consumer ethical behavior than affective empathy, stressing the importance of developing cognitive empathy through various methods. Programs designed to increase empathy have been employed in many prison treatment programs (Ross \& Ross, 1995; Serin \& Kuriychuk, 1994). One method used to increase a person's ability to empathize involves role-playing exercises about another person's feelings to help people understand the pain of others (Andreasen \& Konrath, 2011; Upright, 2002).

The results of this study shed light on the debate as to whether empathy is best conceptualized as an affective or cognitive construct (Jollifee \& Farrington, 2004; Mehrabian, 1997; Wispe, 1987). The present study shows that both constructs have different effects on consumer ethical behaviors. Nonetheless, in the context of Indonesia, both constructs of empathy had no influence on NO HARM and DOWNLOAD behaviors. This may be explained by the fact that software piracy in extremely prevalent in Indonesia, especially among young consumers (Business Software Alliance, 2011). Most consumers 
consider pirating software and downloading illegal copies of movies and music as acceptable behaviors. The Indonesian government and business communities need to educate people about intellectual property rights and the consequences of digital piracy on Indonesian music, film, publishing, and other creative industries. These efforts are needed to significantly change consumer perspectives in Indonesia.

\section{Compassion}

The results show that compassion has a negative influence on consumers' perception toward most unethical behaviors (except for NO HARM and DOWNLOAD behaviors) and a positive influence on ethical behaviors. These findings suggest that compassionate consumers are less likely to engage in unethical behaviors and more likely to recycle and perform good deeds toward others. Thus, one way to increase compassion is by educating people about the consequences of their actions. Individuals often believe that their actions, whether ethical or unethical, have no impact on others and, therefore, often ignore a small act of kindness. Educators need to increase compassion by promoting the belief that even a small act of kindness can make a difference and that a small act of harm can produce unintended consequences.

Similar to the case with empathy, compassion did not influence NO HARM or DOWNLOAD behaviors. As previously discussed, digital piracy in Indonesia is perceived as acceptable and not unethical. Thus, consumers do not feel obliged to buy non-pirated or genuine software, music, and movies. Government, businesses, and education institutions should collaborate to educate consumers about the unethical nature and unintended consequences of digital piracy. 


\section{Machiavellianism}

The results showed that desire for control and distrust of others had a positive influence on consumers' perception toward most unethical behaviors and had no effect on ethical behaviors (RECYCLE and DOING GOOD behaviors). These findings extend and confirm those of other studies showing that Machiavellianism has a negative effect on consumer ethical behaviors (Al-Khatib et al., 1997; Effmeyer et al., 1999). While nothing can be done to change this type of personality, one way to reduce Machiavellianism behaviors is through prevention (Paulhus \& Williams, 2002). Clear rules and regulations by governments and businesses regarding consumer ethics may deter Machiavellian individuals from taking advantage of others.

\section{Limitations and Future Research}

Conducting cross-national research is often very challenging, especially in the context of consumer ethical behavior (Effmeyer et al., 1999). Thus, it is important to discuss the limitations of the present study. This study was conducted in a country that is currently experiencing economic and social problems, both of which may affect the emotions of consumers and the direction of their responses. The study was also conducted within a single metropolitan area in Indonesia.

Future studies should employ experimental methods that use various ethical and unethical scenarios to study the causes and effects of empathy, compassion, and Machiavellianism in these situations. A further limitation of this study is that the sample population consisted mostly of younger consumers.

The limitations of this study do not, however, negate the importance of the findings. Indeed, at this exploratory stage of research, generalizations are usually limited. Future research should be conducted to determine the generalizability of the results of this study by 
investigating older consumers from various geographical locations in Indonesia. In addition, exploring the effects of consumer demographics such as age, income, education, and religious orientation on ethical behaviors would be helpful for understanding consumer ethics across cultures. 


\section{References}

Albiero, P., Matricardi, G., Speltri, D., \& Toso, D. (2009). The assessment of empathy in adolescence: A contribution to the Italian validation of the "Basic Empathy Scale". Journal of Adolescence, 32(2), 393-408.

Al-Khatib, J. A., Vitell, S. J., \& Rawwas, M. Y. (1997). Consumer ethics: a cross-cultural investigation. European Journal of Marketing, 31(11/12), 750-767.

Arli, D., \& Tjiptono, F. (2013). The End of Religion? Examining the Role of Religiousness, Materialism, and Long-Term Orientation on Consumer Ethics in Indonesia. Journal of Business Ethics, 1-16.

Anderson, P. \& Konrath, S. (2011). Why Should We Care?'-What to Do About Declining Student Empathy. Retrieved from http://chronicle.com/article/Why-Should-We-CareWhat $/ 128420 /$.

Bandura, A. (1999). Moral disengagement in the perpetration of inhumanities. Personality and social psychology review, 3(3), 193-209.

Barnett, M. A., Feighny, K. M., \& Esper, J. A. (1983). Effects of anticipated victim responsiveness and empathy upon volunteering. The Journal of Social Psychology, 119(2), 211-218.

Barnett, M. A., \& Thompson, S. (1985). The role of perspective taking and empathy in children's Machiavellianism, prosocial behavior, and motive for helping. The journal of genetic psychology, 146(3), 295-305.

Batson, C. D., Harris, A. C., McCaul, K. D., Davis, M., \& Schmidt, T. (1979). Compassion or compliance: Alternative dispositional attributions for one's helping behavior. Social Psychology Quarterly, 405-409.

Batson, C. D., Chang, J., Orr, R., \& Rowland, J. (2002). Empathy, attitudes, and action: Can feeling for a member of a stigmatized group motivate one to help the group?. Personality and Social Psychology Bulletin, 28(12), 1656-1666.

Block-Lerner, J., Adair, C., Plumb, J. C., Rhatigan, D. L. and Orsillo, S. M. (2007), The case for mindfulness-based approaches in the cultivation of empathy: Does nonjudgmental, present-moment awareness increase capacity for perspective-taking and empathic concern?. Journal of Marital and Family Therapy, 33:501-516. doi: 10.1111/j.17520606.2007.00034.x

Burke, D. M. (2001). Empathy in sexually offending and nonoffending adolescent males. Journal of Interpersonal Violence, 16(3), 222-233.

Bush, C. A., Mullis, R. L., \& Mullis, A. K. (2000). Differences in empathy between offender and nonoffender youth. Journal of Youth and Adolescence,29(4), 467-478. 
Business Software Alliance. (2011). Well over half the world's computer users admit pirating software, BSA study finds. Retrieved from http://www.bsa.org/country/News\%20and\%20Events/News\%20Archives/global/05152012idc-globalpiracystudy.aspx?sc_lang=en

Callahan, S. (1988). The role of emotion in ethical decision making. Hastings Center Report, 18(3), 9-14.

Christie, R., Geis, F. L., \& Berger, D. (1970). Studies in Machiavellianism (p. 106). New York: Academic Press.

CIA World FAcbook (2013). Indonesia. Retrieved from: https://www.cia.gov/library/publications/the-world-factbook/geos/id.html

Dahling, J. J., Whitaker, B. G., \& Levy, P. E. (2009). The development and validation of a new Machiavellianism scale. Journal of management, 35(2), 219-257.

Dovidio, J. F., \& Penner, L. A. (2001). Helping and altruism. Blackwell handbook of social psychology: Interpersonal processes, 162-195.

Davis, M. A., Andersen, M. G., \& Curtis, M. B. (2001). Measuring ethical ideology in business ethics: A critical analysis of the ethics position questionnaire. Journal of Business Ethics, 32(1), 35-53.

Eisenberg, N., \& Miller, P. A. (1987). The relation of empathy to prosocial and related behaviors. Psychological bulletin, 101(1), 91.

Enderle, G., \& Niu, Q. (2012). Discerning ethical challenges for marketing in China. Asian Journal of Business Ethics, 1(2), 143-162.

Erffmeyer, R. C., Keillor, B. D., \& LeClair, D. T. (1999). An empirical investigation of Japanese consumer ethics. Journal of Business Ethics, 18(1), 35-50.

Ferrell, O. C., \& Gresham, L. G. (1985). A contingency framework for understanding ethical decision making in marketing. Journal of marketing,49(3).

Gaudine, A., \& Thorne, L. (2001). Emotion and ethical decision-making in organizations. Journal of Business Ethics, 31(2), 175-187.

George, J. M., \& Bettenhausen, K. (1990). Understanding prosocial behavior, sales performance, and turnover: a group-level analysis in a service context. Journal of applied Psychology, 75(6), 698.

Harpur, T. J., Hakstian, A. R., \& Hare, R. D. (1988). Factor structure of the Psychopathy Checklist. Journal of consulting and clinical psychology, 56(5), 741.

Hawley, P. H. (2003). Prosocial and coercive configurations of resource control in early adolescence: A case for the well-adapted Machiavellian. Merrill-Palmer Quarterly (1982-), 279-309. 
Hwang, J. Y., Plante, T., \& Lackey, K. (2008). The development of the santa clara brief compassion scale: An Abbreviation of Sprecher and Fehr's Compassionate Love Scale. Pastoral Psychology, 56(4), 421-428.

Hunt, S. D., \& Chonko, L. B. (1984). Marketing and machiavellianism. The Journal of Marketing, 30-42.

Hunt, S. D., \& Vitell, S. J. (2006). The general theory of marketing ethics: A revision and three questions. Journal of Macromarketing, 26(2), 143-153.

Jolliffe, D., \& Farrington, D. P. (2004). Empathy and offending: A systematic review and meta-analysis. Aggression and violent behavior, 9(5), 441-476.

Jolliffe, D., \& Farrington, D. P. (2006). Development and validation of the Basic Empathy Scale. Journal of adolescence, 29(4), 589-611.

Lazarus, R. S. (1991). Emotion and adaptation (p. 557). New York: Oxford University Press.

Leiberg, S., Klimecki, O., \& Singer, T. (2011). Short-term compassion training increases prosocial behavior in a newly developed prosocial game. PloS one,6(3), e17798.

Marcus, R. F., \& Gray Jr, L. (1997). Close relationships of violent and nonviolent African American delinquents. Violence and victims, 13(1), 31-46.

Mehrabian, A. (1997). Relations among personality scales of aggression, violence, and empathy: Validational evidence bearing on the risk of eruptive violence scale. Aggressive Behavior, 23(6), 433-445.

Miller, P. A., \& Eisenberg, N. (1988). The relation of empathy to aggressive and externalizing/antisocial behavior. Psychological bulletin, 103(3), 324.

Muncy, J. A. and Vitell, S. J. (1992). Consumer ethics: An empirical investigation of the ethical beliefs of the final consumer. Journal of Business Research 24(1), 297-312.

Muncy, J. A. and Eastman, J. K. (1998). Materialism and consumer ethics: An exploratory study. Journal of Business Ethics 171(1), 137-145.

Paulhus, D. L., and Williams, K. M. (2002). The dark triad of personality: Narcissism, Machiavellianism, and psychopathy. Journal of research in personality, 36(6), 556-563.

Piff, P. K., Stancato, D. M., Côté, S., Mendoza-Denton, R., \& Keltner, D. (2012). Higher social class predicts increased unethical behavior. Proceedings of the National Academy of Sciences, 109(11), 4086-4091.

Rallapalli, K. C., Vitell, S. J., Wiebe, F. A., \& Barnes, J. H. (1994). Consumer ethical beliefs and personality traits: An exploratory analysis. Journal of Business Ethics, 13(7), 487-495.

Radey, M., \& Figley, C. R. (2007). The social psychology of compassion. Clinical Social Work Journal, 35(3), 207-214. 
Rawwas, M. Y. A. (1996). Consumer ethics: An empirical investigation of the ethical beliefs of Austrian consumers. Journal of Business Ethics, 15(9), 1009-1019.

Rawwas, M. Y. A., Strutton, D. and Johnson, L. W. (1996). An exploratory investigation of the ethical values of American and Australian consumers. Journal of Direct Marketing 10, $52-63$

Rawwas, M. Y.A. (2001). Culture, personality and morality: A typology of international consumers' ethical beliefs. International Marketing Review, 18(2), 188-211.

Rawwas, M. Y. A. and Singhapakdi, A. (1998, Spring). Do consumers' ethical beliefs vary with age: A substantiation of Kohlberg's Typology in marketing. Journal of Marketing Theory and Practice 6, 26-38.

Rawwas, M. Y.A., Vitell, S. J., and Al-Khatib, J. A. (1994). Consumer ethics: The possible effects of terrorism and civil unrest on the ethical values of consumers. Journal of Business Ethics, 13(3), 223-231.

Rawwas, M. Y. A., Patzer, G. and Vitell, S. J. (1998). A cross cultural investigation of the ethical values of consumers: The potential effect of war and civil disruption. Journal of Business Ethics 17, 435-448.

Ross, R. R., and Ross, R. (Eds.). (1995). Thinking straight: The reasoning and rehabilitation program for delinquency prevention and offender rehabilitation. Air Training and Publications.

Serin, R. C., and Kuriychuk, M. (1994). Social and cognitive processing deficits in violent offenders: Implications for treatment. International Journal of Law and Psychiatry, 17(4), 431-441.

Sprecher, S., and Fehr, B. (2005). Compassionate love for close others and humanity. Journal of Social and Personal Relationships, 22(5), 629-651.

Staub, E. (1987). Commentary on Part 1. In Empathy and Its Development, edited by N. Eisenberg and J. Strayer. 103-15. Cambridge: Cambridge University Press.

Underwood, B., and Moore, B. (1982). Perspective-taking and altruism. Psychological Bulletin, 91(1), 143.

Upright, R. L. (2002). To tell a tale: The use of moral dilemmas to increase empathy in the elementary school child. Early Childhood Education Journal,30(1), 15-20.

Van Kenhove, P., Vermeir, I. and Verniers, S. (2001). An empirical investigation of the relationships between ethical beliefs, ethical ideology, political preference and need for closure. Journal of Business Ethics 32, 347-361.

Van Kleef, G. A., Oveis, C., Van der Löwe, I., LuoKogan, A., Goetz, J., and Keltner, D. (2008). Power, Distress, and Compassion Turning a Blind Eye to the Suffering of Others. Psychological Science, 19(12), 1315-1322. 
Vitell, S. J. (2003). Consumer ethics research: Review, synthesis and suggestions for the future. Journal of Business Ethics, 43(1-2), 33-47.

Vitell, S. J., Lumpkin, J. R., and Rawwas, M. Y. (1991). Consumer ethics: an investigation of the ethical beliefs of elderly consumers. Journal of Business Ethics, 10(5), 365-375.

Vitell, S. J. and Muncy, J. (2005). The Muncy-Vitell consumer ethics scale: A modification and application. Journal of Business Ethics 62, 267-275.

Vitell, S. J. and Paolillo, G. P. (2003). Consumer ethics: The role of religiousness. Journal of Business Ethics 11, 151-162.

Wispé, L. (1987). History of the Concept of Empathy.

Watson, D., Clark, L. A., and Tellegen, A. (1988). Development and validation of brief measures of positive and negative affect: the PANAS scales. Journal of personality and social psychology, 54(6), 1063.

Wolfson, S. L. (1981). Effects of Machiavellianism and communication on helping behavior during an emergency. British Journal of Social Psychology,20(3), 189-195. 


\section{Appendix}

Table 1. Demographic Profile

\begin{tabular}{llc}
\hline Demographic & & Percentage \\
\hline Age & $18-20$ years old & $83 \%$ \\
& $21-23$ years old & $14 \%$ \\
& 24 and above & $3 \%$ \\
Gender & Male & $33 \%$ \\
& Female & $67 \%$ \\
\multirow{3}{*}{ Marital status } & & \\
& Single & $92 \%$ \\
& Married & $5 \%$ \\
\hline
\end{tabular}


Table 2. Correlation Matrix

\begin{tabular}{|c|c|c|c|c|c|c|c|c|c|c|c|c|c|c|}
\hline & Mean & SD & 1 & 2 & 3 & 4 & 5 & 6 & 7 & 8 & 9 & 10 & 11 & 12 \\
\hline 1. ACT & 1.92 & 0.63 & 1 & & & & & & & & & & & \\
\hline 2. PASS & 2.03 & 0.76 & $0.52 * *$ & 1 & & & & & & & & & & \\
\hline 3. QUEST & 2.32 & 0.67 & $0.51 * *$ & $0.66 * *$ & 1 & & & & & & & & & \\
\hline 4. NOH & 3.13 & 0.97 & $0.28 * *$ & $0.36^{* *}$ & $0.53 * *$ & 1 & & & & & & & & \\
\hline 5. DL & 3.49 & 0.78 & $0.16^{* *}$ & $0.31 * *$ & $0.37 * *$ & $0.46^{* *}$ & 1 & & & & & & & \\
\hline 6. REC & 3.23 & 0.63 & $-0.10^{*}$ & $-0.18 * *$ & $-0.14 * *$ & -0.06 & $0.12 * *$ & 1 & & & & & & \\
\hline 7. GOOD & 3.33 & 0.72 & $-0.18 * *$ & $-0.36^{* *}$ & -0.28 & $-0.18 * *$ & 0.05 & $0.28 * *$ & 1 & & & & & \\
\hline 8. AEMP & 1.27 & 0.29 & 0.04 & 0.04 & 0.12 & 0.04 & $0.26^{* *}$ & 0.08 & 0.08 & 1 & & & & \\
\hline 9. CEMP & 3.67 & 0.51 & $-0.14 * *$ & $-0.17 * *$ & $-0.13 * *$ & 0.01 & $0.12 * *$ & $0.17 * *$ & $0.18^{* *}$ & $0.18^{* *}$ & 1 & & & \\
\hline 10. COMP & 3.72 & 0.56 & $-0.20 * *$ & $-0.23 * *$ & $-0.17 * *$ & -0.07 & 0.02 & $0.20 * *$ & $0.20 * *$ & $0.13 * *$ & $0.47 * *$ & 1 & & \\
\hline 11. DFC & 2.86 & 0.81 & $0.15^{* *}$ & $0.14 * *$ & $0.21 * *$ & $0.22 * *$ & $0.17 * *$ & 0.06 & -0.03 & $0.16^{* *}$ & $0.19 * *$ & 0.07 & 1 & \\
\hline 12. DOO & 2.90 & 0.75 & $0.20 * *$ & $0.24 * *$ & $0.29 * *$ & $0.21 * *$ & $0.27 * *$ & 0.02 & -0.04 & $0.17 * *$ & 0.02 & -0.08 & $0.34 * *$ & 1 \\
\hline
\end{tabular}

Note: ACT=Actively Benefiting; PASS=Passively Benefiting; QUEST=Questionable Behavior; NOH=No harm/ No Foul; DL=Downloading; REC=Recycling;

GOOD=Doing Good; AEMP=Affective Empathy; $C E M P=C$ ognitive Empathy; $D F C=$ Desire for Control; DOO=Distrust of Others.

$* \mathrm{p}<0.05 ; * * \mathrm{p}<0.01$ 
Table 3. Factor Loading and Reliability Scores

\begin{tabular}{|c|c|c|}
\hline Scale items & $\begin{array}{l}\text { Factor } \\
\text { Loading }\end{array}$ & $\begin{array}{l}\text { Cronbach } \\
\text { Alpha }\end{array}$ \\
\hline \multicolumn{3}{|l|}{ Consumer ethics } \\
\hline \multicolumn{3}{|l|}{ Actively benefiting } \\
\hline Returning damaged merchandise when the damage is your fault. & 0.655 & \multirow[t]{4}{*}{0.626} \\
\hline Giving misleading price information to a clerk for an unpriced item & 0.678 & \\
\hline Drinking a can of soda in a store without paying it & 0.669 & \\
\hline $\begin{array}{l}\text { Reporting a lost item as stolen to an insurance company in order to collect } \\
\text { the money. }\end{array}$ & 0.772 & \\
\hline \multicolumn{3}{|l|}{ Passively benefiting } \\
\hline Lying about a child's age in order to get a lower price. & 0.690 & \multirow[t]{3}{*}{0.730} \\
\hline $\begin{array}{l}\text { Not saying anything when the waitress miscalculates the bill in your } \\
\text { favour. }\end{array}$ & 0.878 & \\
\hline Observing someone shoplifting and ignoring it. & 0.843 & \\
\hline \multicolumn{3}{|l|}{ Questionable behavior } \\
\hline Using an expired coupon for merchandise. & 0.669 & \multirow[t]{5}{*}{0.745} \\
\hline $\begin{array}{l}\text { Returning merchandise to a store by claiming it was a gift when it was } \\
\text { not. }\end{array}$ & 0.745 & \\
\hline Using a coupon for merchandise you did not buy. & 0.630 & \\
\hline Not telling the truth when negotiating the price of a new automobile. & 0.754 & \\
\hline Stretching the truth on an income tax return. & 0.734 & \\
\hline \multicolumn{3}{|l|}{ No-harm } \\
\hline Installing software on your computer without buying it. & 0.727 & \multirow[t]{3}{*}{0.660} \\
\hline Burning a CD instead of buying it. & 0.786 & \\
\hline Using a computer software or games that you did not buy. & 0.873 & \\
\hline \multicolumn{3}{|l|}{ Downloading } \\
\hline Downloading music from the internet instead of buying it. & 0.871 & \multirow[t]{2}{*}{0.682} \\
\hline $\begin{array}{l}\text { Buying counterfeit goods instead of buying the original manufacturers } \\
\text { brands. }\end{array}$ & 0.871 & \\
\hline \multicolumn{3}{|l|}{ Recycling } \\
\hline $\begin{array}{l}\text { Purchasing something made of recycled materials even though it is more } \\
\text { expensive. }\end{array}$ & 0.775 & \multirow[t]{3}{*}{0.549} \\
\hline $\begin{array}{l}\text { Buying only from companies that have a strong record of protecting the } \\
\text { environment. }\end{array}$ & 0.724 & \\
\hline Recycling materials such as cans, bottles, newspapers etc. & 0.676 & \\
\hline \multicolumn{3}{|l|}{ Doing good } \\
\hline $\begin{array}{l}\text { Returning to the store and paying for an item that the cashier mistakenly } \\
\text { did not charge you for. }\end{array}$ & 0.803 & \multirow[t]{2}{*}{0.500} \\
\hline Giving a larger than expected tip to a waiter or waitress. & 0.620 & \\
\hline \multicolumn{3}{|l|}{ Affective empathy } \\
\hline My friend's emotions affect don't me too much.(r) & 0.813 & \multirow[t]{4}{*}{0.797} \\
\hline I find it easy to know when my friends are frightened. & 0.655 & \\
\hline Other people's feelings bother me. & 0.777 & \\
\hline I can usually work out when my friends are scared. & 0.724 & \\
\hline \multicolumn{3}{|l|}{ Cognitive empathy } \\
\hline I can often understand how people are feeling even before they tell me. & 0.596 & \multirow[t]{8}{*}{0.846} \\
\hline Seeing a person who has been angered has no effect on my feelings. (r) & 0.724 & \\
\hline I can usually work out when people are cheerful. & 0.682 & \\
\hline I tend to feel scared when I am with friends who are afraid. & 0.754 & \\
\hline I can usually realise quickly when a friend is angry. & 0.619 & \\
\hline I often get swept up in my friend's feelings. & 0.769 & \\
\hline My friend's unhappiness doesn't makes me feel anything. $(r)$ & 0.680 & \\
\hline I have no trouble figuring out when my friends are happy. (r) & 0.749 & \\
\hline
\end{tabular}


Table 3. Factor Loading and Reliability Scores (Continued)

Compassion

\begin{tabular}{|l|l}
\hline I try to be understanding and patient towards those aspects of my & 0.798
\end{tabular}

0.799

I'm kind to myself when I'm experiencing suffering.

When I'm going through a very hard time, I give myself the caring and tenderness I need.

I'm tolerant of my own flaws and inadequacies.

0.816

I try to be loving towards myself when I'm feeling emotional pain.

Desire for Control

I like to give the orders in interpersonal situations.

I enjoy being able to control the situation.

I enjoy having control over other people.

Distrust of Other

People are only motivated by personal gain.

0.737

I dislike committing to groups because I don't trust others.

Team members backstab each other all the time to get ahead.

If I show any weakness at work, other people will take advantage of it.

0.597

0.776

Other people are always planning always to take advantage of the

situation at my expense. 
Table 4. Regression Analyses

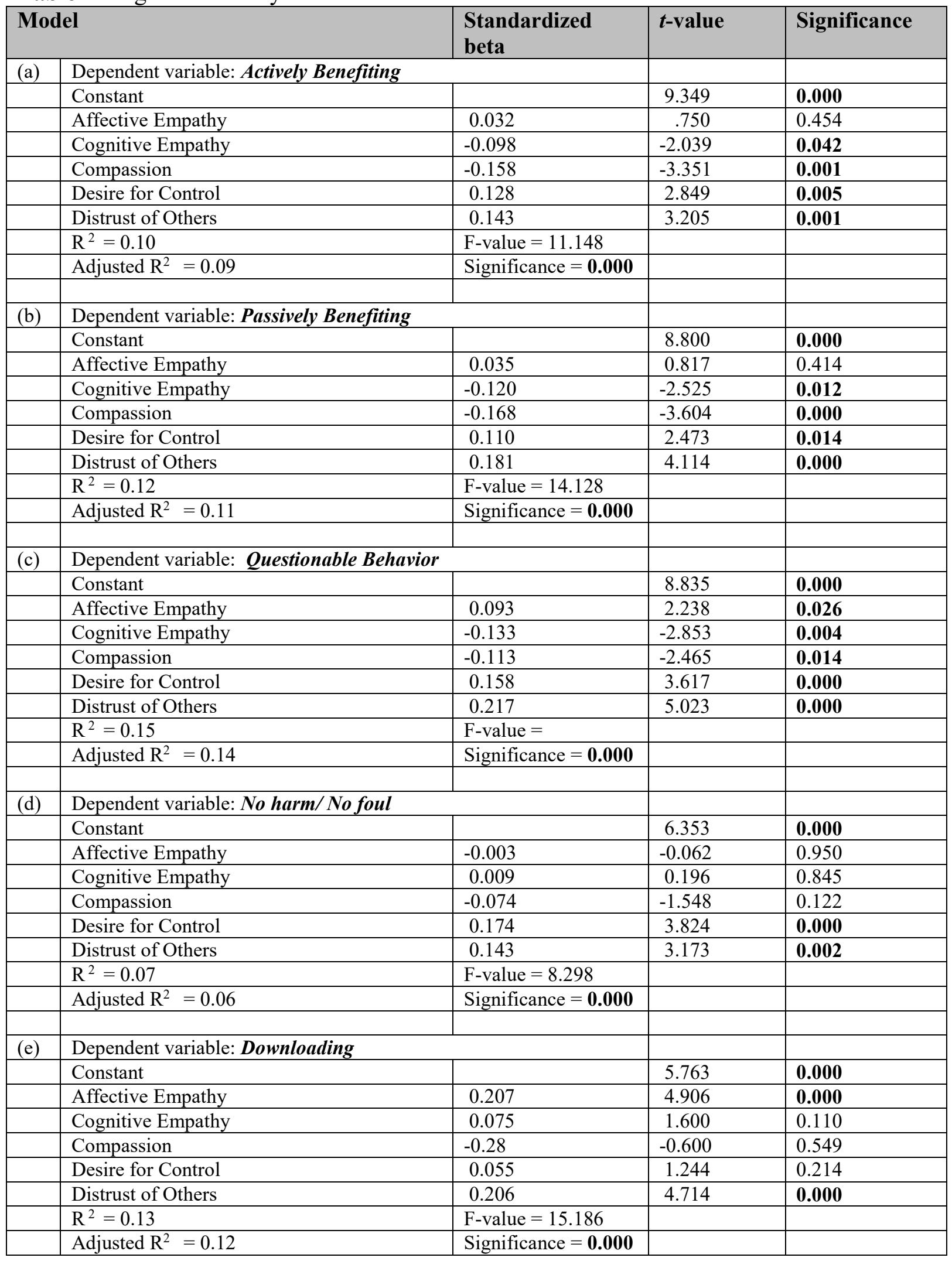


Table 4. Regression Analyses (Continued)

\begin{tabular}{|l|l|l|l|l|}
\hline \multicolumn{2}{|l|}{ Model } & $\begin{array}{l}\text { Standardized } \\
\text { beta }\end{array}$ & t-value & Significance \\
\hline (f) & Dependent variable: Recycling & & & \\
\hline & Constant & 0.037 & 7.995 & $\mathbf{0 . 0 0 0}$ \\
\hline & Affective Empathy & 0.085 & 0.846 & 0.398 \\
\hline & Cognitive Empathy & 0.153 & 1.732 & 0.084 \\
\hline & Compassion & 0.023 & 3.162 & $\mathbf{0 . 0 0 2}$ \\
\hline & Desire for Control & 0.018 & 0.495 & 0.621 \\
\hline & Distrust of Others & F-value $=5.518$ & 0.393 & 0.695 \\
\hline & $\mathrm{R}^{2}=0.05$ & Significance $=\mathbf{0 . 0 0 0}$ & & \\
\hline & Adjusted R $\mathrm{R}^{2}=0.04$ & & & \\
\hline & \multicolumn{2}{|l|}{} & & \\
\hline (g) & Dependent variable: Doing Good & & 7.497 & $\mathbf{0 . 0 0 0}$ \\
\hline & Constant & 0.051 & 1.168 & 0.243 \\
\hline & Affective Empathy & 0.114 & 2.337 & $\mathbf{0 . 0 2 0}$ \\
\hline & Cognitive Empathy & 0.141 & 2.926 & $\mathbf{0 . 0 0 4}$ \\
\hline & Compassion & -0.063 & -1.383 & 0.167 \\
\hline & Desire for Control & -0.019 & -0.421 & 0.167 \\
\hline & Distrust of Others & F-value $=6.184$ & & \\
\hline & $\mathrm{R}^{2}=0.06$ & Significance $=\mathbf{0 . 0 0 0}$ & & \\
\hline & Adjusted R $\mathrm{R}^{2}=0.05$ & &
\end{tabular}


Table 5: Summary of Hypothesis Results

\begin{tabular}{|c|c|}
\hline Hypothesis & Result \\
\hline \multicolumn{2}{|c|}{$\mathbf{H}_{1}$ : Affective empathy is a negative determinant of consumer ethical beliefs regarding: } \\
\hline (a) actively benefiting behavior & Rejected \\
\hline (b) passively benefiting behavior & Rejected \\
\hline (c) questionable behavior & Rejected \\
\hline (d) no-harm/no-foul behavior & Rejected \\
\hline (e) downloading/ buying counterfeit goods & Rejected \\
\hline \multicolumn{2}{|l|}{ and positive determinant of: } \\
\hline (f) recycling/environmental awareness & Rejected \\
\hline (g) doing the right thing/doing good. & Rejected \\
\hline \multicolumn{2}{|c|}{$\mathbf{H}_{2}$ : Cognitive empathy is a negative determinant of consumer ethical beliefs regarding: } \\
\hline (a) actively benefiting behavior & Supported \\
\hline (b) passively benefiting behavior & Supported \\
\hline (c) questionable behavior & Supported \\
\hline (d) no-harm/ no-foul behavior & Rejected \\
\hline (e) downloading/buying counterfeit goods & Rejected \\
\hline \multicolumn{2}{|l|}{ and positive determinant of: } \\
\hline (f) recycling/environmental awareness & Rejected \\
\hline (g) doing the right thing/doing good. & Supported \\
\hline \multicolumn{2}{|c|}{$\mathbf{H}_{3}$ : Compassion is a negative determinant of consumer ethical beliefs regarding: } \\
\hline (a) actively benefiting behavior & Supported \\
\hline (b) passively benefiting behavior & Supported \\
\hline (c) questionable behavior & Supported \\
\hline (d) no-harm/no-foul behavior & Rejected \\
\hline (e) downloading/buying counterfeit goods & Rejected \\
\hline \multicolumn{2}{|l|}{ and positive determinant of: } \\
\hline (f) recycling/environmental awareness & Supported \\
\hline (g) doing the right thing/doing good. & Supported \\
\hline \multicolumn{2}{|c|}{ H: Desire to control is a positive determinant of consumer ethical beliefs regarding: } \\
\hline (a) actively benefiting behavior & Supported \\
\hline (b) passively benefiting behavior & Supported \\
\hline (c) questionable behavior & Supported \\
\hline (d) no-harm/no-foul behavior & Supported \\
\hline (e) downloading/buying counterfeit goods & Rejected \\
\hline \multicolumn{2}{|l|}{ and negative determinant of: } \\
\hline (f) recycling/environmental awareness & Rejected \\
\hline (g) doing the right thing/doing good. & Rejected \\
\hline \multicolumn{2}{|c|}{ H5: Distrust of other is a positive determinant of consumer ethical beliefs regarding: } \\
\hline (a) actively benefiting behavior & Supported \\
\hline (b) passively benefiting behavior & Supported \\
\hline (c) questionable behavior & Supported \\
\hline (d) no-harm/ no-foul behavior & Supported \\
\hline (e) downloading/ buying counterfeit goods & Supported \\
\hline \multicolumn{2}{|l|}{ and negative determinant of: } \\
\hline (f) recycling/environmental awareness & Rejected \\
\hline (g) doing the right thing/doing good. & Rejected \\
\hline
\end{tabular}

